
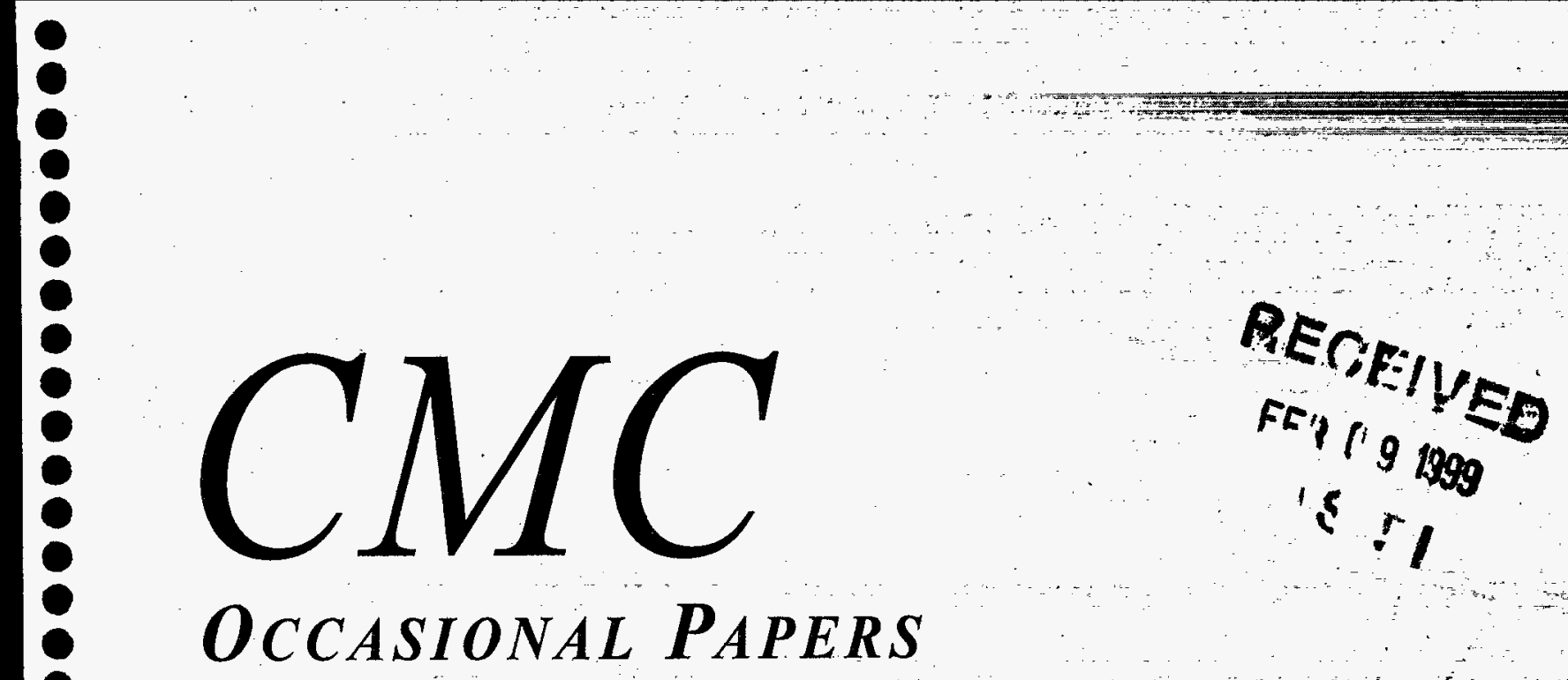

\title{
Pakistani Perceptions and Prospects of Reducing the Nuclear Danger in South Asia
}

Nazir Kamal

Security Analyst

Islamabad, Pakistan 
Issued by Sandia National Laboratories, operated for the United States Department of Energy by Sandia Corporation.

NOTICE: This report was prepared as an account of work sponsored by an agency of the United States Government. Neither the United States Government nor any agency thereof, nor any of their employees, nor any of their contractors, subcontractors, or their employees, makes any warranty, express or implied, or assumes any legal liability or responsibility for the accuracy, completeness, or usefulness of any information, apparatus, product, or process disclosed, or represents that its use would not infringe privately owned rights. Reference herein to any specific commercial product, process, or service by trade name, trademark, manufacturer, or otherwise, does not necessarily constitute or imply its endorsement, recommendation, or favoring by the United States Government, any agency thereof, or any of their contractors or subcontractors. The views and opinions expressed herein do not necessarily state or reflect those of the United States Government, any agency thereof, or any of their contractors.

Printed in the United States of America. This report has been reproduced directly from the best available copy.

Available to DOE and DOE contractors from Office of Scientific and Technical Information PO Box 62

Oak Ridge, TN 37831

Prices available from (615) 576-8401, FTS 626-8401

Available to the public from

National Technical Information Service

US Department of Commerce

5285 Port Royal Rd.

Springfield, VA 22161

NTIS price codes

Printed Copy: A03

Microfiche Copy: A01 


\section{DISCLAIMER}

Portions of this document may be illegible in electronic image products. Images are produced from the best available original document. 


\title{
Pakistani Perceptions and Prospects of Reducing the Nuclear Danger in South Asia
}

\author{
Nazir Kamal \\ Security Analyst \\ Islamabad, Pakistan
}

Cooperative Monitoring Center Occasional Paper/6

\section{Sandia National Laboratories}

Sandia is a multiprogram laboratory operated by Sandia Corporation, a Lockheed Martin Company, for the United States Department of Energy under contract DE-AC04-94AL85000. 
The Cooperative Monitoring Center (CMC) at Sandia National Laboratories assists political and technical experts from around the world to acquire the technology-based tools they need to assess, design, analyze and implement nonproliferation, arms control and other cooperative security measures. As part of its mission, the CMC sponsors research on cooperative security and the role of technology. Reports of that work are provided through the Occasional Papers series. Research is conducted by Sandia staff as well as visiting scholars. The CMC visiting scholars program is administered by the Institute for Public Policy at the University of New Mexico. For additional information on the programs of the CMC, visit the CMC home page on the World Wide Web at <http://www.cmc.sandia.gov> or write to:

Cooperative Monitoring Center

Sandia National Laboratories

Mail Stop 1373

Albuquerque, NM 87185-1373

For specific information on this report contact:

Kent L. Biringer at the above address.

This report was prepared by Sandia National Laboratories

Albuquerque, NM 87185 and Livermore, CA 94550 


\title{
Pakistani Perceptions and Prospects of Reducing the Nuclear Danger in South Asia
}

\begin{abstract}
The Indian and Pakistani nuclear tests in May 1998 triggered a full-blown nuclear debate. For the first time, hard-liners, moderates, and pacifists engaged in an extensive public discussion that helped to make the people of Pakistan more sensitive to the dangers of nuclear competition.

Pakistan's concerns about its conventional military inferiority, both in the present and future, and the belief that nuclear capability would deter India from exerting its superior military strength, constituted the bedrock of its perception on the nuclear issue. Official Pakistani statements, both immediately after the nuclear tests and later, have advocated restraint on the issue of nuclearization, indicating cognizance of the importance of avoiding a regional nuclear arms competition, both for security and economic reasons.

This paper suggests a variety of nonweaponization and nondeployment options that would serve the security interests of India and Pakistan. Besides preventing a hair-trigger situation, these options could reduce the financial and logistical burden of ensuring the safety and security of nuclear weapons as well as lower strategic threat-perceptions.
\end{abstract}


This page intentionally left blank. 


\section{Contents}

EXECUTIVE SUMMARY . .9

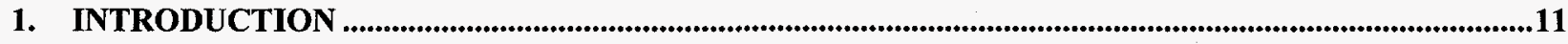

2. NUCLEAR PERCEPTIONS IN THE PRE-TEST PERIOD ....................................................................11

2.1 BACKGROUND .11

2.2 PUBLIC OPINION SURVEYS .12

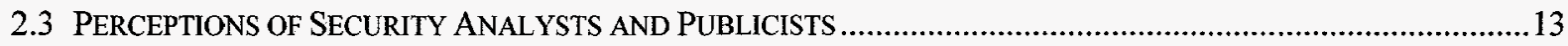

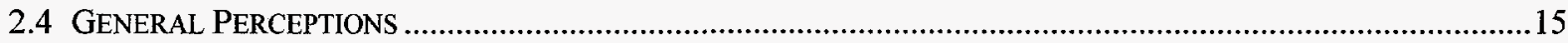

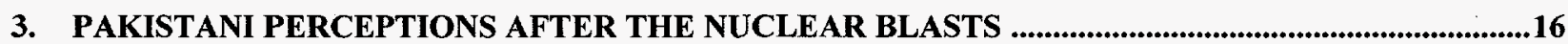

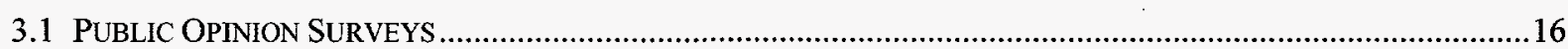

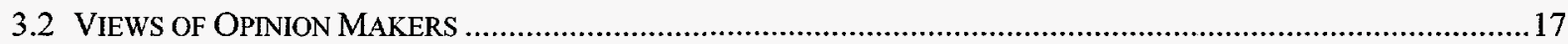

4. REDUCING THE NUCLEAR DANGER IN SOUTH ASIA AND ITS PROSPECTS ..................................23

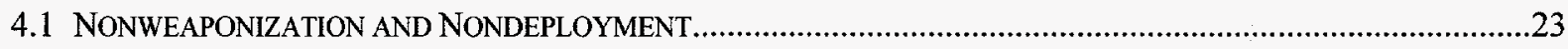

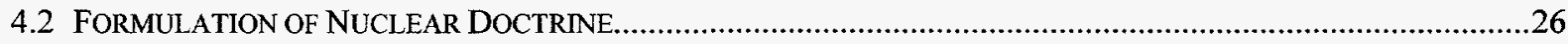

4.3 Hot LINE BETWEEN INDIAN AND PAKISTANI PRIME MINISTERS..................................................................26

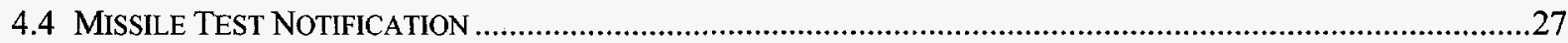

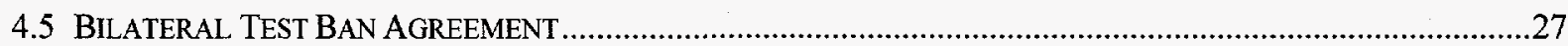

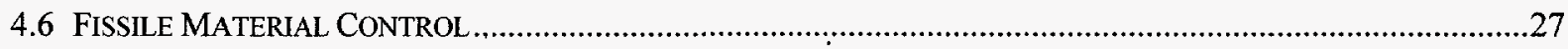

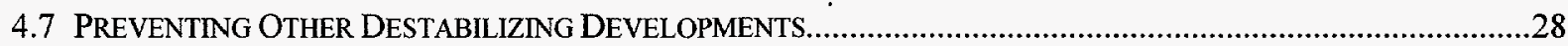

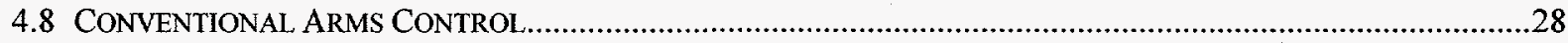

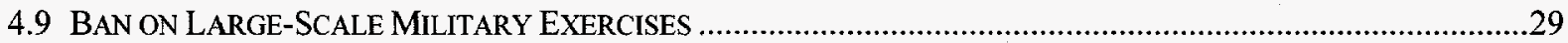

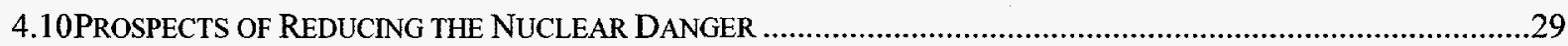

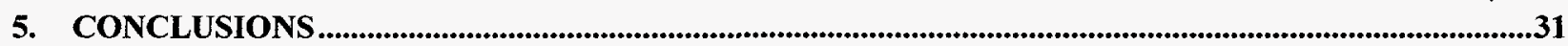

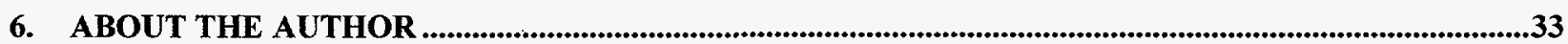




\section{Acronyms}

CBM confidence-building measures

CMC Cooperative Monitoring Center

CTBT Comprehensive Test Ban Treaty

FMCT Fissile Material Cut-off Treaty

NPT Non-Proliferation Treaty

NTM National Technical Means

TELs Transporter/Erector/Launchers 


\section{Pakistani Perceptions and Prospects of Reducing the Nuclear Danger in South Asia}

\section{Executive Summary}

The Indian and Pakistani nuclear tests in May 1998 were greeted by their respective publics with unsettling jubilation. But that euphoria died down quickly as it became increasingly clear that a perilous road lay ahead. International sanctions also dampened the excitement by bringing into sharper relief the economic and social problems of the region, one of the world's poorest.

The atomic tests triggered a full-blown nuclear debate. For the first time, the hard-liners, moderates, and pacifists engaged in an extensive public debate. On balance, that unprecedented debate helped to make the people of Pakistan more sensitive to the dangers of nuclear competition than the political rhetoric to which they had been subjected previously.

The high-level talks that the United States soon initiated with both India and Pakistan also helped to focus attention on the dangers of nuclear competition and the need for India and Pakistan to reflect on their security policies and postures.

Pakistan's concerns about its conventional military inferiority, both in the present and future, and the belief that nuclear capability would deter India from exerting its superior military strength constituted the bedrock of its perception on the nuclear issue from the outset.

Yet there has been little support among influential opinion makers for an active program of nuclearization (unless India embarks on that path). There is also broad appreciation of the need for an elaborate command and control system for safeguarding and managing the country's nuclear capability.

Official statements, both immediately after the nuclear tests and later, have advocated restraint on the issue of nuclearization, indicating cognizance of the importance of avoiding a regional nuclear arms competition, both for security and economic reasons.

It is critically important that India and Pakistan avoid going further down the nuclear road. A buildup of operational capabilities would be difficult to keep to a bare minimum and, worse, it would create a hair-trigger situation that would heavily tax both governments as well as put their societies under an acute psychological strain. Ensuring strategic stability in the political, geographical, and demographic context of South Asia would be an exacting task.

Although India has pledged a no-first-use policy, that policy would lose much of its relevance if it went down the nuclear road, since Pakistan would have to respond to capabilities rather than declared intention.

Nonweaponization or nondeployment would serve the security interests of India and Pakistan eminently. Besides preventing a hair-trigger situation, it would reduce the financial and 
logistical burden of ensuring the safety and security of nuclear weapons. It would also lower strategic threat-perceptions.

Equally, if a conventional conflict erupted, nonweaponization or nondeployment in peace time would give the belligerents some time to control the conflict as well as cogitate the deployment of nuclear weapons for deterrence. Outside powers would also have some time to mount diplomatic efforts to avert a possible disaster.

Mutual suspicion and national sensitivities are likely to restrict the scope of measures to achieve strategic stabilization, as agreements for nonweaponization or nondeployment would require means of monitoring compliance that may be deemed too intrusive. India and Pakistan could, however, engage in a tacit understanding for nonweaponization and nondeployment of delivery systems in peace time and for a discreet mechanism for clarifying or correcting controversial situations. As a first step, they could announce a moratorium on nonweaponization and nondeployment.

For nondeployment, they could also consider storing Transporter/Erector/ Launchers (TELs) of missiles in designated sites, thereby leaving out the sensitive issue of monitoring missiles. Again, regional National Technical Means (NTM) may need supplementation by thirdparty satellite reconnaissance and periodic on-site monitoring of TELs. Nondeployment could also cover specific categories of nuclear-capable aircraft in all forward air bases. The no-fly zones (agreed to in their 1991 accord on preventing air-space violation) could be extended appropriately to cover specified categories of aircraft.

India and Pakistan should also undertake to renounce the development of new systems, such as sea-based nuclear missiles and submarines capable of launching those missiles. Such developments would weaken strategic stability, besides opening up a new area of nuclear competition.

Linked to preventing a nuclear competition is the need for modest nuclear doctrines. While India should seek to reinforce its no-first-use pledge with restraint in the development of nuclear capabilities, Pakistan needs to minimize reliance on nuclear deterrence for its security to the fullest extent possible.

The nuclear danger could also be reduced through conventional stability, as a nuclear exchange could arise from an escalation of conventional conflict. A force-limitation zone along the border would lower armament levels in forward positions and eliminate the threat of surprise attack, thereby greatly reducing the risk of conflict.

While unmitigated adversaries may balk at intrusive verification measures, some form of monitoring would be necessary to ensure strategic stability and build mutual confidence. It could be designed to minimize intrusiveness.

Finally, India and Pakistan should treat the issues of strategic stabilization and restraint as a special case, so that progress in this area does not depend on the overall progress of their bilateral talks, as that could mean an indefinite wait. 


\section{Pakistani Perceptions and Prospects of Reducing the Nuclear Danger in South Asia}

\section{Introduction}

The Indian and Pakistani nuclear tests in May 1998 were greeted by their respective publics with unsettling jubilation. But that euphoria died down quickly as it became increasingly clear that a perilous road lay ahead. International sanctions also dampened the excitement by bringing into sharper relief the economic and social problems of the region, one of the world's poorest. In Pakistan, the sanctions brought the country to the brink of financial collapse. Nothing could have been more revealing than the Government's decision to suspend the constitution and freeze the foreign currency accounts held in Pakistan by both resident and overseas Pakistanis. The grim economic conditions and general concern about the Government's ability to stem the domestic crisis, after initial optimism, also humbled most politicians who had earlier spoken in hyperbolic terms about the security benefits that would accrue from a demonstrated nuclear capability.

The nuclear tests triggered a full-blown nuclear debate. For the first time, the hard-liners, moderates, and pacifists engaged in an extensive public debate. On balance, that unprecedented debate helped to make the people of Pakistan more sensitive to the dangers of nuclear competition than the political rhetoric to which they had been subjected previously.

The high-level talks that the United States soon initiated with both India and Pakistan also helped to focus attention on the dangers of nuclear competition and the need for India and Pakistan to reflect on their security policies and postures. The nuclear tests also increased domestic and international pressure on India and Pakistan to resume their stalled bilateral talks, which began again in October 1998 and are expected to be a sustained effort to achieve progress.

This paper discusses Pakistani official and nongovernmental perceptions on the issue of nuclearization, starting with the perceptions that prevailed before the nuclear tests. Next, it discusses Pakistan's policy on nuclearization and the prospects of reducing the nuclear danger in South Asia. The discussion on prospects includes the role of cooperative monitoring.

\section{Nuclear Perceptions in the Pre-Test Period}

\subsection{Background}

Concerns about conventional military inferiority, both in the present and future, and the belief that nuclear capability would deter India from exerting its superior military strength to dominate Pakistan constituted the bedrock of Pakistani perceptions on the nuclear issue. Nuclear self-denial was also rejected because India, besides enjoying conventional military superiority, would then also possess a nuclear monopoly over Pakistan. India had become a nascent nuclear power since its 1974 nuclear device test and it was strongly opposed to joining the nuclear NonProliferation Treaty (NPT) as a nonnuclear weapon state. 
During the period from 1987 (when Pakistan claimed to have acquired the means to make nuclear weapons) ${ }^{1}$ up to the time of the nuclear tests in May 1998, the country witnessed a general national decline. ${ }^{2}$ A lack of national self-confidence seemed apparent in the way many public figures and other opinion makers tended to magnify and even distort the country's nuclear achievements. In some cases, such tendencies seemed aimed at promoting self-serving agendas. Likewise, some strata of influential opinion tended to exaggerate the role of nuclear weapons by not fully appreciating the nature of deterrence involving weapons of mass destruction, especially in the context of South Asia's geographical, demographic, and other realities.

The nuclear hype was also sustained by the view, which some mainstream opinion makers projected with complete self-assurance, that Pakistan's nascent nuclear capability was the decisive factor that had allegedly deterred India from going to war during the 1987 and 1990 crises, which were defused with U.S. assistance. ${ }^{3}$

\subsection{Public Opinion Surveys}

On the whole, the public gravitated toward the official policy, which was one of restraint, even if the Government's moderate stance could be partly attributed to outside pressures on a country that depended significantly on external assistance, especially from the United States, for its military and economic sustenance.

The first systematic public opinion survey in Pakistan on issues devoted exclusively to the nuclear question was carried out roughly two years before the Pakistani nuclear tests. ${ }^{4}$ The 1996 survey showed that a clear majority of respondents $(61 \%)$ supported the official policy on nuclear-related issues. This implied that they approved of a policy of not engaging in nuclear device testing or embarking on a weaponization program except as a matching response to such moves by India. Another public opinion survey on national issues carried out in 1997 showed that $84 \%$ of respondents believed that Pakistan should retain the nuclear option (implying that there should be no nuclear renunciation). ${ }^{5}$ It seems (from this survey) that retaining the nuclear option and thus maintaining a capability that could be quickly weaponized was one reason why as many as $50 \%$ of respondents felt that there was no danger of war between India and Pakistan

\footnotetext{
${ }^{1}$ Dr. A.Q. Khan, Pakistan's leading nuclear scientist, claimed after the nuclear tests that Pakistan had acquired "nuclear capability" in late 1984. See "Pakistan making equipment for N-plants: Qadeer," Dawn, August 19, 1998.

2 This decline was marked by political polarization, economic mismanagement, ethnic/sectarian strife, weakening of the country's conventional military strength, political and administrative corruption, and political interference in the functioning of most State institutions. Another major factor for the decline was the negative political, social, and cultural impact on the country of its role as a front-line state in the U.S.-sponsored war against Soviet military intervention in Afghanistan during the 1980s.

${ }^{3}$ While the 1987 crisis was triggered by the largest Indian military exercise along the Pakistani border carried out under "Operation Brasstacks," the 1990 crisis was initially linked to an armed uprising in Indian-controlled Kashmir, which India accused Pakistan of fomenting and assisting.

${ }^{4}$ Samina Ahmed, et al., Pakistan's Nuclear Choices, a report sponsored by The Fourth Freedom Forum and The John B. Kroc Institute for International Peace Studies, University of Notre Dame, August 1996. The survey reflects the perceptions of the urban elite rather than the general public. The survey's sample size consisted of 910 urbanbased people from various professions, of whom $68 \%$ had no political affiliation.

5 See "82\% Pakistanis want to stay home; most hopeful of future," Dawn, March 23, 1997. The Karachi-based Herald, a monthly political magazine, conducted the survey. Its findings were based on responses from 1,260 people from all the major urban centers of Pakistan.
} 
in the foreseeable future. In the earlier 1996 survey, those advocating the development of nuclear weapons (thereby implicitly supporting nuclear testing independently of India's action) constituted just under one-third of the respondents.

On the specific question of nuclear testing, a majority opposed it, but only by a relatively small margin (52\% against, $48 \%$ in favor). But support for testing rose sharply when the question was asked whether Pakistan should conduct a test if India carried out a second test (the first one being the 1974 explosion). Those advocating a countervailing response represented $73 \%$ of all respondents, including $68 \%$ of supporters of official policy and $93 \%$ of nuclear advocates. While $80 \%$ of all respondents considered the nuclear issue to be "very important," only $28 \%$ thought it was the most important one. The Kashmir dispute, ethnic and sectarian strife, economic stability, the Afghan refugee problem, and poverty (in that order) were deemed more important and they were all rated well above the nuclear issue.

The 1996 survey also showed that a majority of respondents, including most hard-liners, favored nuclear renunciation by Pakistan if a similar renunciation by India could be obtained and verified. Similarly, almost all the supporters of official policy, as well as the nuclear advocates, were in favor of Pakistan adhering to the NPT if India undertook to do the same.

The two surveys showed some discrepancies, such as the inconsistency of responses to questions about the NPT and the circumstances that would justify nuclear renunciation by Pakistan. Perhaps, in part, this could be explained by limited familiarity with nuclear issues and with the politics of Pakistan's nuclear diplomacy. It should be noted that only $6 \%$ of respondents said that the country's nuclear policy was a major area of interest to them professionally, and only $24 \%$ felt that they were sufficiently well informed about that policy. As one senior journalist observed piquantly in 1994: "There has been so much secrecy about the nuclear programme that it is very difficult to discuss it in any meaningful way." 6 On the whole, the survey indicated that the Government could mobilize sufficient support to carry on with its policy of restraint on the nuclear issue, despite concerns about the country's declining conventional military balance with India as well as periodic pressure from the pro-bomb lobby to push ahead with nuclear testing and the development of nuclear weapons.

\subsection{Perceptions of Security Analysts and Publicists}

The balance of opinion among the better informed and the more influential community of security analysts and publicists (many of whom were former government functionaries) also favored the official policy of restraint and ambiguity. Significantly, most senior retired military officers seemed satisfied with the official policy as long as the Government did not succumb to external pressure, notably from the U.S., to roll back the country's nuclear program without a similar restriction being put upon India. For example, retired General Arif wrote: "If South Asia is to be denuclearised, India has to lead the way in a meaningful and verifiable manner. The American advice for a 'standstill', as that country's previous demand of 'capping, rollback and

\footnotetext{
${ }^{6}$ M.A. Niazi, "Lifting the nuclear veil," The News (Pakistan), September 2, 1994.
} 
elimination' of the nuclear programme, is worthy of consideration only if it is simultaneously and equally applied to India and Pakistan."7

This standpoint apparently enjoyed broad support, both in the 1980s and 1990s, though there appeared to be some increase in the number of pro-bomb advocates during this period, as in the number of nuclear pacifists who opposed nuclearization on grounds of either moral, security, or environmental concerns. ${ }^{8}$ In large part, the hawkish stance emanated from the religious fundamentalist parties, notably the Jamaat-i-Islami, as well as from some fundamentalist-leaning political figures and commentators. Other hard-liners were influenced more by nationalistic notions. In most cases, such sections of society advocated a hard-line policy toward India on all issues, including military confrontation over the Kashmir dispute.

(Many) security analysts and publicists... also favored the official policy of restraint and ambiguity.

Some public figures, too, had spoken of the value of nuclear weapons in a manner that encouraged the perception that nuclear weapons would guarantee (rather than help in strengthening) Pakistan's security vis-à-vis India as well as elevate the country's standing in the international community. ${ }^{9}$ For example, General Hamid Gul, a former intelligence chief with fundamentalist leanings, portrayed Pakistan's nuclear capability and its further development to be an asset for the security of the Muslim world rather than just Pakistan. He also said that nuclear power would turn Pakistan into the most powerful Muslim military power-a position from which the country could pursue radical pan-Islamic objectives and secure its future by becoming an important part of a bigger political and military entity.

In addition, most fundamentalist and nonfundamentalist hard-liners looked upon nuclear weapons as providing the country with a security cover for initiating Government-backed operations to assist the militancy in Indian-controlled Kashmir. They saw diminishing prospects of dislodging India from that disputed territory by other means. Although some of them seemed unsure about the effectiveness of the nuclear security cover, they were still prepared to risk a costly full-scale war with India over Kashmir. Yet, interestingly, the 1996 public opinion survey showed that such views made little or no impression on the respondents whose exclusive concern was deterring India from waging a war or from enlarging the conflict in Indian-controlled Kashmir beyond the Line of Control.

\footnotetext{
${ }^{7}$ General K.M. Arif, "Lengthening nuclear shadows," Dawn (Pakistan), September 6, 1994. General Arif was Chief of General Staff in the Pakistan army during the military rule of General Ziaul Haq.

${ }_{8}$ The pro-bomb proponents far outnumbered the nuclear pacifists, the latter being partly disadvantaged by a political milieu in which dissident or unconventional views are generally treated with disdain, if not distrust (though lately there is less intolerance). One of earliest groups of pacifists is the Pakistan Forum, which notably includes some scientists. The Pakistan Human Rights Commission, a non-governmental organization, is another notable group that advocates pacifism.

See, for example, H.K. Burki, "The nuclear games adventurers play," The News, September 3, 1994.
} 


\subsection{General Perceptions}

While there is little data about perceptions of the general public, ${ }^{10}$ except for scattered anecdotal information, it seems that popular interest in the nuclear issue had diminished by the mid-1990s. This could be attributed to various factors, as follows:

1. There was public disenchantment with the confounding statements by political leaders and their exploitation of the nuclear issue for ulterior motives in a climate of power politics. Political alienation, too, had begun to affect the general public, as evidenced by low voter turnout at the elections despite enormous investment of political and financial resources in the electoral campaigns. ${ }^{11}$

2. It is also possible that the public had accepted the low-level deterrence relationship that had emerged between India and Pakistan, which seemed fairly stable, sustainable, and sufficient (unless one side or the other rocked the boat).

3. Another factor could have been the growing sense of alarm about the country's deteriorating economic situation as well as mounting concerns about internal security (ethnic/sectarian violence and terrorism, especially in the Punjab and Sind provinces) and the steady breakdown of general law and order.

As one commentator observed: "The nuclear question has finally lost whatever political punch it had." $" 12$ This did not, however, discourage political mavericks and politically motivated commentators from continuing to play "nuclear football" in the public arena, even if it damaged Pakistan's image overseas as a country that could be trusted to manage nuclear deterrence responsibly. ${ }^{13}$

Nevertheless, official policy stayed on the moderate course, goaded along that path in part by external pressure. Thus, Pakistan showed little intention of disturbing its low-level nuclear equation with India, though it continued to oppose joining the NPT and the Comprehensive Test Ban Treaty (CTBT) without India participating in those regimes as well (a position it had been pursuing from the beginning, backed by strong domestic consensus).

During much of this pretest period (1980s-1998), periodic pressure from the U.S. for unilateral nuclear renunciation by Pakistan encouraged the hard-liners to step up their rhetoric in support of the view that the nuclear option was far too important for the country's security to brook any discussion on its limitation.

\footnotetext{
${ }^{10}$ Approximately $65 \%$ to $70 \%$ of the Pakistani population is illiterate.

11 The last election in early 1997 saw a voter turnout of less than $40 \%$, with much lower turnouts being reported for most urban centers. Overall turnout also became a subject of controversy, with many political figures and others claiming or suspecting a lower turnout than the official figure of roughly $38 \%$.

${ }_{12}$ Shah Khan, "Our bomb, right or wrong," The News, September 1, 1994.

${ }^{13}$ H.K. Burki, "The nuclear games adventurers play," The News, September 3, 1994. Burki, a veteran journalist, coined the term "nuclear football." Aptly, he said: "Pakistan has the unique distinction of being the only country where nuclear football is played." See also Munir Ahmad Khan, "Price of nuclear rhetoric," The News, September 19, 1994. Munir Ahmad Khan, a former Chairman of the Pakistan Atomic Energy Commission, observed: "Unfortunately, our public figures have been notorious for exploiting the nuclear issue for personal and selfish ends."
} 
Thus, external pressures helped to sensitize the nuclear issue domestically, making the hard-liners more assertive and giving them a lever with which to dominate the security debate. ${ }^{14}$ As a result, hawkish rhetoric, partly motivated by self-serving agendas and partly by suspicion of U.S. motives, drowned out the fewer voices that sought a free and informed discussion on security issues and the country's nuclear diplomacy.

While the nuclear status quo continued, much of Pakistan's effort in the 1990s was devoted to developing missile delivery systems, an area in which India had been devoting considerable resources since the early 1980s under its Integrated Guided Missile Development Programme.

India's promising missile achievements by the late 1980 s and early 1990 s had raised Pakistani threat-perceptions of a strategic gap. That gap was partly bridged in August 1997 when Pakistan successfully tested a $600-\mathrm{km}$-range missile named Hatf-3. The missile gap was virtually closed in April 1998 following the successful testing of a medium-range missile, Ghauri, which enabled Pakistan to reach potential targets over much of mainland India. ${ }^{15}$

\section{Pakistani Perceptions After the Nuclear Blasts}

\subsection{Public Opinion Surveys}

The balance of Pakistani opinion on the nuclear issue was disturbed by the Indian tests on May 11, 1998, as that major event changed the nuclear status quo and threatened to spark a destabilizing process of weaponization. Thus, the tests by India altered the context that had shaped Pakistani perceptions.

An opinion poll conducted two weeks after the Indian tests but before the Pakistani tests on May 28, 1998, showed that $70 \%$ of urban Pakistanis favored immediate testing. However, the grave financial crisis prevailing in the country did have some impact on the public (if not to the same degree on politicians and opinion makers). While $6 \%$ of respondents opposed a response, some $30 \%$ favored a delay until economic conditions in the country had normalized. ${ }^{16}$

The threat of international sanction also played some role but not to a significant extent. More interesting was the public response to inducement for restraint. Nearly $50 \%$ said that Pakistan should observe nuclear abstinence if international lenders would alleviate its external debt burden as a reward for nuclear restraint. ${ }^{17}$

\footnotetext{
${ }^{14}$ At that time, the political culture was more restrictive than it is today for an open debate on security issues.

${ }^{15}$ In order to compensate for India's far greater geographical depth, Pakistan needed missiles with ranges beyond the short range.

16 "Gallup poll shows 70\% urban Pakistanis want nuclear test, only $6 \%$ outrightly reject conducting nuclear test," News Network International (Pakistan), May 28, 1998. The poll was conducted by the Pakistan Institute of Public Opinion for Gallup International. The sample size consisted of 500 men and women from a cross section of age, education, and income groups in the four provincial capitals of Pakistan. See also "Gallup shows $90 \%$ people repose confidence in Govt's policies," News International Network, June 10, 1998.

${ }_{17}$ Pakistan's foreign debt has been estimated at more than $\$ 32$ billion, with a growing proportion in short-term liabilities. Its balance of payments deficit is in the range of $\$ 5$ billion, while its foreign currency reserves have been
} 
The survey also showed that almost $60 \%$ of respondents favored restraint if China, considered a dependable ally of Pakistan, advised against testing.

Another opinion poll conducted a few days before the Pakistani tests yielded somewhat different results. While nearly two-thirds of respondents wanted an immediate response to the Indian tests, only one-sixth favored delaying it to some later date.. ${ }^{18}$ The responses differed according to the respondent's educational level. Only $43 \%$ of the highest degree holders supported an immediate explosion, compared to $58 \%$ of college graduates and $76 \%$ of those The Pakistani nuclear tests generated greater public approval of testing than in the pre-test period. with high school certificates.

The Pakistani nuclear tests generated greater public approval of testing than in the pretest period. A Gallup poll showed that $85 \%$ of respondents expressed happiness with the tests. Though $30 \%$ of respondents in the pre-test poll had preferred a delay in testing, they were not opposed to it in principle. India's hard-line statements directed at Pakistan immediately after the Indian tests and the public jubilation in India may have also been contributory factors.

The post-test survey also showed that $51 \%$ of urban Pakistanis believed that international sanctions would be severe, while as many as $37 \%$ believed they would be mild. Only $15 \%$ said that there would be no difficulty. Importantly, most respondents believed that the Government would be able to surmount the challenge posed by the sanctions.

For the first time, economic factors figured prominently in the debate, thereby enlarging its parameters. Only several weeks before the nuclear tests, the Army chief himself had said that the country's economic mess posed a greater threat to national security than external dangers. ${ }^{19}$

\subsection{Views of Opinion Makers}

Public perceptions would have been influenced by the views of public figures and influential opinion makers. The nuclear tests spawned an unprecedented debate on nuclear issues, in which hard-liners, moderates, and pacifists made their pitch. Before the nuclear tests, the debate had been the preserve of a select group of commentators (mainly former government functionaries), with the debate being shaped by the official agenda.

Regarding the role of hard-liners in the situation preceding the Pakistani tests, a veteran Pakistani analyst observed: "A striking feature of the current crop of Pakistani hawks is a neartotal absence of facts and analyses. The emotional quotient is high instead. There are strident,

\footnotetext{
well under $\$ 1$ billion in recent months. Pakistan's economy has also been in a recession for the past several years, while the inflow of foreign capital dropped sharply during this period.

${ }^{18}$ Mehtab Karim, "Figuring it out," Newsline, June 1998. The survey was done by Newsline, a leading Karachibased monthly. The survey consisted of 850 adults over the age of 20 with different educational levels.

19 "Poor economy greater threat than that from Outside: COAS," Dawn, May 5, 1998.
} 
apocalyptic warnings that if Pakistan does not now conduct nuclear tests, it shall cease to be a sovereign state, becoming a dependency of the United States and a vassal of India.,"20

For example, General Arif believed that Pakistan had "a one-time chance to demonstrate its nuclear capability here and now (as tomorrow may prove too late)," while retired Lt. General Ghulam Umar said a matching response was the only option, "encompassing total requirements of strategic and tactical nuclear weapons." 21

Support for testing was not unanimous among the senior retired military officers. For example, retired General Mirza Aslam Beg advocated conducting nuclear tests at an appropriate time, as there was no need for haste because Pakistan already possessed a "credible nuclear deterrent."22 Retired Lt. General Javed Nasir lamented the jubilation shown by Indians and Pakistanis after their respective nuclear tests, as he considered nuclear rivalry to be dangerous for regional security. ${ }^{23}$

The nuclear tests spawned an unprecedented debate on nuclear issues.

There seemed to be more civilian hawks than military hawks among the circle of influential opinion makers. As a nuclear moderate noted: "(Those whose views are) the most difficult to swallow have been our ideologues and politicians." On the role of politicians, he added: "Most of them sense in this crisis an opportunity to win popularity, put undue and irresponsible pressure on government at a time when national security demands deep deliberation and diplomacy."24

Former Prime Minister Benazir Bhutto also supported an early response, claiming that India may risk a war with Pakistan over Kashmir, as failure to test would imply that Pakistan did not possess a credible nuclear deterrent. ${ }^{25}$

Among civilians, the strongest pressure came from the Jamaat-i-Islami. Its party chief, Qazi Hussain Ahmad, said: "If the Government fails to (conduct tests) under any American

\footnotetext{
${ }^{20}$ Eqbal Ahmad, "Hawks make strange bedfellows," Dawn, May 24, 1998.

${ }^{21} \mathrm{Ibid}$. Gen. Omar is a former head of the Pakistan Institute of International Affairs, a governmental research organization based in Karachi.

${ }_{22}$ General Beg was the army chief in the late 1980 s and early 1990 s. After retirement, he established an organization that participated actively in holding seminars and produced research papers and publicist material on security issues. Gen. Beg is also the head of a political party. He was initially in favor of an immediate test but believed that since the Government had lost that opportunity, it was better to wait for an appropriate time. He did not explain the reasons for his initial or subsequent position. "Pakistan must demonstrate N-capability, says Beg," Dawn, May 19, 1998. Another opponent of testing was Air Marshal Rashid Shaikh, who argued that sanctions would hurt the country at a time when economic revival should have been a higher priority. See "Nuclearisation and Pakistan's strategic dilemma," The Nation, September 15, 1998.

23 Javed Nasir, "Aftermath of the nuclear fever," The Nation, August 4, 1998. Lt. Gen. Nasir is a former chief of intelligence. He writes frequently and forcefully in the Pakistan print media.

${ }^{24}$ Ibid.

25 "Benazir fears Indian attack on Kashmir," Dawn, May 18, 1998.
} 
pressure, it will mean a surrender of our sovereignty and enslaving the country to the United States... and India's hegemonic designs will receive a boost in the region." 26

In the situation preceding the Pakistani tests, the hardliners far outweighed the pacifists but the situation also gal-

The post-test euphoria died down quickly, aided by the country's grim economic conditions, which international sanctions made more precarious. vanized the latter to articulate their position more forcefully than at any other time in the past. Thus, a coalition of regional political parties and some human rights organizations urged the Government to unilaterally renounce nuclear weapons and resist pressure from "across the political and religious spectrum in Pakistan (who) are clamouring for giving a fitting reply to India." 27

As one analyst observed: "Judging from the columns and letters in newspapers, (the 'doves') are not only numerous but a majority (of them) also write on the question of Pakistan's options dispassionately and knowledgeably.,28

Those opposed to testing included some leading political analysts. One of them said pointedly that the Government should have waited out the Indian government's euphoria and "let the fallout of its folly prove its undoing." 29

Although a big majority favored immediate testing and a bigger majority welcomed the tests, most opinion makers, both military and civilian, showed more cool-headedness on the broader issues of nuclearization.

The post-test euphoria died down quickly, aided by the country's grim economic conditions, which international sanctions made more precarious. The grimness of the situation became evident when the Government declared a national emergency and suspended the constitution immediately after the nuclear tests, while it continued to face difficulty in tackling the economic crisis, not to mention other national problems. ${ }^{30}$

While some public figures and opinion makers urged the Government to directly assist the militancy in Indian-controlled Kashmir, even at the risk of igniting another war with India, ${ }^{31}$

26 "Subcontinent starts sliding into an arms race," International Herald Tribune, May 12, 1998.

27 "Pakistan asked to renounce nuclear option," Dawn, May 27, 1998. The coalition accused the hard-liners in both countries of being "blissfully unaware of the mass destruction potential of nuclear weapons. They do not understand that nuclear weapons are evil, mass destroyers of human life and are morally indefensible." The coalition also argued: "An economically stable and fortified Pakistan will be many times more secure than an economically shattered Pakistan with a few nuclear weapons in its arsenal but with a population robbed of their basic human rights to a decent existence."

28 Eqbal Ahmad, "Hawks make strange bedfellows," Dawn, May 24, 1998.

29 Anwar Ahmad, "The trial ahead," The News, June 1, 1998.

${ }^{30}$ A well-known journalist, Zafar Abbass, for example, wrote: "The jubilation that followed in the country was soon dampened by news that the government had decided to take drastic measures in anticipation of the international sanctions that were likely to be imposed on Pakistan." See, "Future shock?" Herald (a Karachi-based monthly), June 1998.

31 Apart from fundamentalists, the most prominent nonfundamentalist figure advocating intervention in Indiancontrolled Kashmir was General Mirza Aslam Beg. 
there was little evidence of support for an active program of nuclearization in nonfundamentalist circles. Both broad public opinion and the balance of opinion among the elite were clearly in favor of restraint, realism, and a responsible approach. Thus, General Arif said that, "the possession of nuclear weapons bestows certain obligations." 32 A former military intelligence chief, retired General Assad Durrani, spoke of the folly of India and Pakistan engaging in a nuclear arms race, both for economic reasons and because of the lessons to be learned from the Cold War era. He advocated a "modest but effective" nuclear philosophy."

Retired Air Marshal Zafar Chaudhry cautioned against misunderstanding the role that nuclear deterrence could play in the security of India and Pakistan. He also pointed to the daunting task of establishing an effective command and control system in the subcontinental environment where "decisions could even be whimsical, impulsive and even unauthorised" in view of the region's volatile political history and its poor record of averting disasters, including munitions-related accidents. ${ }^{34}$

Retired Air Marshal Rashid Shaikh, who had opposed a precipitous response to the Indian tests, regarded nuclear deterrence to be a recipe for "collective suicide" and argued that Pakistan should instead rely almost wholly on conventional forces for its security against India. ${ }^{35}$ Equally scathing were the comments of General Javed Nasir: "To say the least, (Indians and Pakistanis) do not have the foggiest idea as to what can happen to them and to their generations if a nuclear conflict is initiated even accidentally."

Two other former military officers, Air Marshal Asghar Khan and Lt. General Talat Masood, subsequently joined in by urging an end to nuclear competition, saying that a nuclear buildup would increase defense spending, taking more scarce resources away from social and economic development. They also said that the use of nuclear weapons for deterrence would be suicidal. $^{36}$

Most leading civilian commentators also advocated a policy of restraint. For example, one of them described nuclear stabilization to be a paramount regional need and urged measures to avert a conventional conflict, as that was the most likely path to a nuclear escalation. ${ }^{37}$

Another well-known commentator questioned the viability of nuclear deterrence, not because South Asians are more irrational or irresponsible than others but because of the region's

\footnotetext{
32 Gen. K.M. Arif, "Beyond the Explosions," Dawn, June 22, 1998.

33 Assad Durrani, "Our friend, our enemy," The News, June 11, 1998.

34 Zafar Chaudhry, "Averting a nuclear disaster," Dawn, June 23, 1998. Probably the biggest and the most embarrassing munitions-related accident was the one at Ojri depot near the capital city of Islamabad in early 1988. Shells and projectiles flew in all directions well beyond the surrounding area, causing considerable damage to property and loss of human life.

35 Rashid Shaikh, "Post-nuclear scenario," The News, September 24, 1998.

${ }^{36}$ Air Marshal Asghar Khan, a former air force chief, is regarded as the architect of the modern Pakistani air force. He has also been an active political figure since the late 1960 s when he became head of a political party. Lt. Gen. Talat Masood is a former head of the Defense Production Board.

37 Afzal Mahmood, "Security concerns in South Asia," Dawn, October 10, 1998.
} 
legacy of bitterness and the "highly charged and negative images (they have) of each other.",38 Such images and attitudes, he maintained, were potent sources for wars.

In an interesting development, more than a score of retired senior military officers joined the ranks of nuclear pacifists by opposing the concept of nuclear deterrence, both at the regional and global levels. These military officers joined a dozen like-minded Indian counterparts in an appeal for the denuclearization of South Asia and for a shift of emphasis on eliminating poverty and backwardness in the region. ${ }^{39}$

The only prominent advocate of nuclearization, it seems, was a leading nuclear scientist, Dr. Mobarik Mand, who said that Pakistan may need some 60 to 70 nuclear bombs for deterrence with India. ${ }^{40}$ But he also said that deterrence did not really depend on the number of nuclear weapons-a view that had been expressed by former Army chief, General Jahangir Karamat, shortly after the nuclear tests. ${ }^{41}$

To sum up, influential opinion makers have shown little support for an active program of nuclearization (unless India embarks on that path). There is also broad appreciation of the need for an elaborate command and control system for safeguarding and managing the country's nuclear capability. ${ }^{42}$

On specific nonproliferation issues, the balance of opinion does not seem to have been significantly at variance with the pre-test period. Thus, as a Gallup survey conducted

\section{Influential opinion makers have shown little support for an active program of nuclearization (unless India embarks on that path).}

shortly after the nuclear tests showed, nearly $75 \%$ of urban Pakistanis favored joining the CTBT if India did the same. ${ }^{43}$ Similarly, more than $70 \%$ opposed further nuclear testing as long as India observed a moratorium. If India did not do that, $85 \%$ would support a response.

The CTBT issue drew reactions from a large number of public figures and opinion makers as well as some unlikely participants with little past involvement in strategic issues. While the advocates and opponents of CTBT appear fairly evenly balanced, ${ }^{44}$ it seems that a majority would back the official policy of qualified support for CTBT. ${ }^{45}$

\footnotetext{
${ }^{38}$ Inayatullah, "Myths of deterrence," The News, June 1, 1998.

39 "Former military officers oppose arms race," Dawn, October 4, 1998.

${ }^{40}$ See Dawn, June 1, 1998.

${ }^{41}$ According to one journalist (apparently the only one), in some unspecified quarters there was talk of weaponization that ranged from 30 to 70 nuclear weapons for deterrence purposes. M.S. Qazi, "Nuclear force structures in South Asia," The Frontier Post (Pakistan), October 19, 1998.

${ }^{42}$ For concerns about the challenges of establishing command and control, see, for example, M.A. Niazi, "Thinking the unthinkable," The Nation, October 23, 1998.

43 "Majority favour N-arms controls but link it to India," The News, June 10, 1998. Only $23 \%$ favored unilateral signing of the CTBT. Although the results of opinion polls before and after the tests were not basically at odds, more people were prepared to clinch a deal on non-testing after the tests than before the tests.

${ }_{44}$ Perhaps the split opinions on CTBT are best exemplified by the views of two nuclear scientists, one in favor and the other against. Top nuclear scientist Dr. A.Q. Khan supported unilateral signing of the CTBT. Another senior nuclear engineer, Dr. Sultan Bashiruddin Mahmood, joined the public debate for the first time by strongly opposing
} 
Official statements, both immediately after the nuclear tests and later, were moderate on the issue of nuclearization, indicating cognizance of the importance of avoiding a regional nuclear arms competition, both for security and economic reasons. Thus, when breaking the news of the Pakistani nuclear tests, Prime Minister Nawaz Sharif said that Pakistan would continue to exercise "utmost restraint and responsibility." He added that his government would be prepared to discuss all outstanding issues with India, including "urgent steps for mutual restraint and equitable measures for nuclear stabilization." 46

Giving further credibility to the policy of restraint was the Army chief's statement: "This new balance in the military equation could lead to restraint and rationality by learning from the painful process the U.S. and former USSR had gone through in the cold war era.",47

The Pakistani Foreign Office also promptly pitched in. A statement said: "We are not interested in a nuclear or conventional arms race... In the future, too, we will continue to conduct ourselves with restraint and responsibility... While we will not provoke escalation, our responses will be calibrated to respond to any provocation or escalation by India." 48

The theme of restraint and stabilization was pursued at the multilateral Conference on Disarmament in Geneva, a multilateral negotiating body linked to the UN. The Pakistani representative said that his country was "prepared to consider means for mutual restraint which can help to stabilize the nuclear situation in South Asia or through specific measures specially designed for a nuclear restraint regime.",49

Later, in September 1998, Prime Minister Nawaz Sharif spoke about "mutually-agreed measures to avoid war, (and) to create a regime for nuclear restraint and conventional balance" in his speech to the United Nations General Assembly. ${ }^{50}$

The economic crisis impacted nuclear policy. Thus, the lifting of U.S. sanctions has been made a precondition for joining the CTBT. Otherwise, Pakistan's adherence to the CTBT may

the CTBT unless the NPT was modified so that Pakistan could be included as a nuclear-weapon state (a position far removed from official policy and net public perceptions on the CTBT issue). See, respectively, "CTBT signing won't affect our capability: Qadeer," Dawn, September 24, 1998; and "Scientist warns against signing CTBT," Dawn, September 23, 1998. The strongest opponents of signing the CTBT have been the fundamentalists. For example, the chief of Jamaat-e-Islami warned the members of parliament, "You will dig your graves by signing the CTBT ... and we will take out your funeral procession from the National Assembly." Zaigham Khan, "Playing with Fire," Herald, September 1998.

${ }^{45}$ Prime Minister Nawaz Sharif said at the United Nations General Assembly in September 1998 that Pakistan would adhere to the CTBT if India did the same. On unilateral adherence, however, he placed some preconditions, mainly that the sanctions should be lifted and India should not be given preferential terms for signing the CTBT. The statement on CTBT was, however, couched in ambiguity. See, for example, Masood Haider, "PM seeks parity with India on CTBT issue," Dawn, September 24, 1998. There has been considerable concern in Pakistan that the U.S. may offer preferential terms to India for signing the CTBT, as sought by New Delhi.

${ }^{46}$ See "Pakistani's Words: To Restore the Strategic Balance," The New York Times, May 29, 1998.

47 "Pakistan's nuclear tests have corrected the balance: Army chief," Pakistani Press International, May 30, 1998.

48 "Pakistan agrees to exercise restraint," Dawn, June 6, 1998.

49 Statement by Ambassador Munir Akram, Plenary Session of the Conference on Disarmament, June 2, 1998.

${ }^{50}$ See, for example, Amit Baruah, "Indo-Pak talks on the basis of agreed agenda," The Hindu (India), October 15, 1998. 
only be possible if India adhered, too, and on similar terms. The lifting of sanctions by the U.S. has been predicated on substantial progress by Pakistan toward reducing the nuclear danger.

The agreement to resume stalled India-Pakistan talks in October 1998 saw a spate of Pakistani references to the need for nuclear restraint and avoiding the risk of nuclear conflict. In a potentially significant development, Pakistani Foreign Secretary Shamshad Ahmad proposed joint efforts for strategic restraint and a "stabilisation regime covering nuclear weapons, ballistic missiles and conventional forces."

\section{Reducing the Nuclear Danger in South Asia and Its Prospects}

\subsection{Nonweaponization and Nondeployment}

It is critically important that India and Pakistan avoid going further down the nuclear road as a buildup of operational capabilities would be difficult to keep to a bare minimum and, worse, it would create a hair-trigger situation that would heavily tax both governments as well as put their societies under an acute psychological strain.

Ensuring strategic stability in the political, geographical, and demographic context of South Asia would be an exacting task. ${ }^{52}$ A robust command, control, communications, and intelligence system would also be expensive. ${ }^{53}$ If the India-Pakistan relationship continued to remain acrimonious, as is likely, the nuclear danger would be ever present.

Although India has pledged a no-first-use policy, that policy would lose much of its relevance if it went down the ...A buildup of operational capabilities would be difficult to keep to a bare minimum and, worse, it would create a hair-trigger situation... nuclear road, since Pakistan would have to respond to capabilities rather than declared intention. For example, it would be hard for Pakistan to take at face value a declared Indian second-strike capability as it could also be used for a decapitating first strike.

Nuclearization by India against China would also complicate the India-Pakistan equation as a declared China-specific deterrent could be employed against Pakistan.

India does not need to nuclearize against China. China has a no-first-use policy and a conventional conflict between them, as in the past, is most likely to be limited in scope, both

\footnotetext{
${ }^{51}$ Amit Baruah, "Indo-Pak commitment on reducing risk of conflict," The Hindu, October 19, 1998.

${ }^{52}$ Many potential strategic targets on both sides of the border are well within ten minutes of missile launch. Numerous Indian and Pakistan cities have large and dense populations, while many urban areas designated as towns contain large populations. Even nuclear bombs of low kiloton yields would cause horrendous devastation.

${ }^{53}$ India and Pakistan are low-income economies and are also ranked very low in the Human Development Index developed by the United Nations Development Program. Costs to these poor countries with staggering social problems would skyrocket if they succumbed to pressure for constructing civilian nuclear shelters as well as equipping and training their armed forces to operate in a simulated nuclear environment.
} 
geographically and politically. They are also well-matched along the Himalayan frontier. ${ }^{54}$ Furthermore, the danger of conflict between them is much lower than between India and Pakistan, as they have moved toward a significant reduction of border tension over the past decade.

Nor does India need to nuclearize against Pakistan unless perhaps the latter initiates that process. The conventional military balance between them is significantly in India's favor and, as such, Pakistan's military strength does not pose a strategic threat to India. The latter's various structural advantages, including its much larger physical and economic size, would continue to ensure that the conventional balance remains firmly in its favor.

Nonweaponization or nondeployment would serve the security interests of India and Pakistan eminently, as it would prevent a hair-trigger situation and thereby reduce the financial and logistical burden of ensuring the safety and security of nuclear weapons. It would also lower strategic threat-perceptions.

Equally, if a conventional conflict erupted, nonweaponization or nondeployment in peace time would give the belligerents some time to control the conflict as well as cogitate the deployment of nuclear weapons for deterrence, ${ }^{55}$ since an Indo-Pakistani war is likely to take several weeks or perhaps more to reach a critical stage. Outside powers would also have some time to mount diplomatic efforts to avert a possible disaster.

Nonweaponization or nondeployment would serve the security interests of India and Pakistan eminently...

Pakistan has advocated "strategic restraint" and proposed a regime to contain competition in nuclear weapons, ballistic missiles, and conventional forces. The Pakistani framework, though not revealed in any detail, includes nondeployment on a reciprocal basis. ${ }^{56}$ India has yet to spell out its nuclear doctrine beyond no first use, though it has stated an intention not to follow the path pursued by the established nuclear powers. It may be possible, therefore, to persuade India to renounce nuclearization in some shape or form.

India and Pakistan may, however, resist a commitment to keep their delivery systems nonweaponized for political reasons or its verification implications. Implementing that would require data exchanges on missile inventory ${ }^{57}$ and their location, periodic radiation checks on

\footnotetext{
${ }^{54}$ For example, a recent study by the Indian Institute of Defense Studies and Analyses, a think tank funded by the Indian Defense Ministry, believes that "in a conventional military scenario, India would be in a better position to defend itself if a situation like that in 1962 develops in relation to China." See Rifaat Hussain, "Rationalising nuclear India," The News, October 25, 1998. (India lost a limited border conflict in 1962 with China.)

${ }^{55}$ Being militarily weaker, Pakistan would want to keep that option, especially given that its military balance with India is likely to deteriorate further in the near and foreseeable future.

${ }_{56}$ Foreign Minister Sartaj Aziz disclosed that Pakistan had proposed nondeployment on a reciprocal basis during bilateral talks in October 1998. He did not elaborate on the framework in which that proposal had been made. News Today, November 10, 1998, http://www.india-today.com/ntoday $/ 6 \mathrm{html}$. As discussed earlier, there is considerable sentiment among the Pakistani elite and general public for nuclear restraint between India and Pakistan. Notably, there has been little public pressure for unilateral weaponization or deployment.

57 Since they are at a nascent stage of missile production, with some missile programs still at a developmental stage, data exchanges on numbers would pose problems. Nor are they likely to reveal missile characteristics or numbers.
} 
missile nose cones, ${ }^{58}$ and provision for investigating their absence outside designated sites in situations of doubt. It would also require satellite reconnaissance. If nuclear-capable strike aircraft were included, verification may require aerial overflights, if not also spot checks.

Another approach could be to focus attention on the nondeployment of delivery systems. Such a peacetime ban would have to apply to all missiles beyond battlefield range, as it would be difficult to distinguish conventionally armed delivery systems from strategic missiles. ${ }^{59}$ Deployment restrictions could also be imposed on specific nuclear-capable strike aircraft.

Regarding missile nondeployment, one approach could be to place their Transporter/Erector/Launchers (TELs) at designated or declared storage sites. ${ }^{60}$ However, even this may be resisted as it would involve data exchanges and the monitoring of portals of TEL storage sites by means of on-site sensors linked to a remote control station. Or, monitoring could be done by simply applying tamper-proof tags and seals and making periodic checks to tally their numbers. Verification may also require satellite reconnaissance and a provision for investigation if satellite pictures suggested a possible infringement or if an allegation of noncompliance were made on some other basis.

Given the depth of suspicion between India and Pakistan and the technical limitations of their NTM, third-party involvement for cooperative monitoring would be necessary, especially for satellite reconnaissance, periodic inspection, and special investigation. As a first step, therefore, India and Pakistan could make nondeployment commitments through a bilateral pledge rather than a formal agreement. ${ }^{61}$ As for nuclear-capable strike aircraft, their deployment in all forward bases could be prohibited. ${ }^{62}$

In both cases, though, some measure of cooperative monitoring would be necessary in order to discourage cheating. In light of their national sensitivities, what may be possible is monitoring by advanced satellites under a tacit understanding with an acceptable third party or parties, together with a provision for discreet clarification or correction of noncompliance. Though a modest approach, this would have some continuing effect as the diplomatic and political risk of cheating would serve as a disincentive. Some credence would also need to be given to their pledges, if only because their significant reliance on human intelligence-gathering would serve as another disincentive. ${ }^{63}$

In addition, India and Pakistan could update their 1991 confidence building measures (CBM) agreement on the prevention of air-space violations by extending the no-fly zone within

\footnotetext{
58 Radiation detection can be customized to reveal no more than the mere presence or absence of fissile material.

59 If there is too strong a resistance to a zero-missile program, there could be deployment restrictions on conventionally armed missiles, say, by prohibiting their deployment within 300 kilometers of the border. However, compliance may require a third-party role for radiation checks of such missiles. Simple hand-held devices can make such checks.

${ }^{60}$ An advantage with this approach would be that it would not involve monitoring missiles, which would be a far more sensitive matter than focusing on TELs.

61 A bilateral pledge would carry more weight than unilateral declarations.

${ }^{62}$ In the latter case, the process could begin by withdrawing one specified category of aircraft.

${ }^{63}$ The fact that many Indians and Pakistanis share ethnic similarities and the Punjabi and Urdu languages are spoken in parts of both countries makes human intelligence-gathering a valuable instrument.
} 
their borders for specified categories of nuclear-capable aircraft. That in itself could force a withdrawal of those types of aircraft from forward bases.

For nonweaponization of delivery systems, they could make unilateral pledges or declare a moratorium unilaterally, thereby keeping their options open for contingency while exercising restraint as they did during the pre-test period. Unilateral pledges or declarations would create a norm and serve as a constraining factor.

\subsection{Formulation of Nuclear Doctrine}

Both India and Pakistan have made statements about their strategic doctrines. When India made its no-first-use pledge, it said that its doctrine was evolving. It is uncertain what practical shape it intends to give to its pledge. As nuclearization would erode the value of that pledge, India should clothe its no-first-use posture with nonweaponization and nondeployment as the preferred path.

Pakistan has said that its capability was aimed at deterring India both in the nuclear and conventional fields. This is too generalized. In the interest of nuclear stability, it should make a clearer declaration, linking its doctrine to realistic and rational strategic objectives. ${ }^{64}$

An ambitious or ill-conceived deterrence policy by Pakistan may push India into a more competitive nuclear stance. Over-reliance on nuclear deterrence by Pakistan could thus prove counter-productive, dangerous, and financially exorbitant. ${ }^{65}$

As a first step, India and Pakistan should avoid political statements, especially with reference to Kashmir, that could be perceived as nuclear saber rattling, as they have done on occasions. Such saber rattling would create apprehensions about the declarer's nuclear doctrine and may bring the other side under pressure for nuclearization.

\subsection{Hot Line Between Indian and Pakistani Prime Ministers}

Existing hot lines, whether between the heads of Indian and Pakistani governments or between their Director-Generals of Military Operations, have seldom been used, even at times of an escalation of tension. In the post-test situation, Indian and Pakistani leaders need to exercise a greater sense of responsibility 1) toward containing tension so that it does not escalate to a conflict and 2) toward managing other aspects of nuclear stability.

They should therefore establish dedicated hot lines under a formal agreement that establishes the basis for setting up a satellite-based communications link. In this regard, the hot

\footnotetext{
${ }^{64}$ This should be possible, given that the mainstream opinion in Pakistan does not favor stepping onto a slippery nuclear slope unless forced by India. Furthermore, Pakistan does not have to spell out its doctrine in any great detail.

${ }^{65}$ The acquisition of nuclear deterrence should not lower Pakistan's reliance on conventional force to deal with perceived threats to its external security. The prevailing economic crisis and other problems should not lead to expediency in formulating its nuclear doctrine.
} 
line agreement between the U.S. and USSR in 1971 could serve as a working model, both technologically and in terms of the strategic rationale for establishing the links.

\subsection{Missile Test Notification}

An initial confidence-building measure could be a ban on missile tests pointed in the direction of the other side's territory. But since missile tests by India and Pakistan have followed a general north-south trajectory (that is, away from each other's territories), such an agreement would be too modest if it stood alone. An additional CBM could be an agreement for the prior notification of all missile tests, for which relevant portions of the U.S.-USSR accord of 1988 could serve as a model. Another CBM could be notification of space vehicle launches.

\subsection{Bilateral Test Ban Agreement}

Both India and Pakistan have declared a moratorium on nuclear tests and have said that a test ban would not impinge on their security, as the tests conducted in May 1998 have given them an assured capability. ${ }^{66}$

But India remains opposed to embracing CTBT because of some unresolved issues, such as the transfer of dual-use technology ${ }^{67}$ Without India's adherence, CTBT cannot come into force under the treaty's entry-into-force provisions. Thus, India will not be under any obligation to desist from further tests. At some future date, it could set aside its moratorium if another surge of nationalism or considerations of domestic politics should take hold, as witnessed recently when it clandestinely conducted nuclear tests.

Given these problems, legal assurance of non-testing could come from a bilateral test ban agreement. This would obviate India's difficulties with the CTBT and in the event that India decided to join CTBT, the proposed bilateral agreement would be superseded or allowed to lapse. ${ }^{68}$

\subsection{Fissile Material Control}

A Fissile Material Cut-off Treaty (FMCT) would cap weaponization if it proved difficult to prevent nuclearization. Although India and Pakistan have dropped their opposition to negotiations for such a treaty, there are contentious issues that could complicate FMCT negotiations.

\footnotetext{
${ }^{66}$ Leading defense scientists in both countries have said that CTBT would not adversely affect their country's deterrence capability.

${ }^{67}$ The transfer of such technology is prohibited under the Nonproliferation Treaty, the guidelines of the Nuclear Suppliers Group, and the Missile Technology Control Regime.

${ }_{68}$ The bilateral agreement could replicate the escape clause in the CTBT so that it does not impose greater restriction than CTBT.
} 
Pakistan is concerned that FMCT would create a significant imbalance in stockpiles, since India is believed to possess a much larger inventory. ${ }^{69}$ If weaponization occurs, or if it cannot be kept to a nominal level, India would be able to field an arsenal large enough to raise doubts about the credibility of Pakistan's deterrence. ${ }^{70}$ Advocacy of an ambitious program for nuclearization by some Indian quarters has reinforced Pakistan's concern. ${ }^{71}$

Thus, the negotiations for a cut-off treaty would benefit from a nonweaponization agreement between India and Pakistan. A nondeployment commitment, though important in itself, would do less to alleviate Pakistan's problems with FMCT.

\subsection{Preventing Other Destabilizing Developments}

India and Pakistan should also undertake to renounce the development of new systems, such as sea-based nuclear missiles and submarines capable of launching those missiles. India has announced that it plans to begin those programs in the near future. ${ }^{72}$ Unless such developments can be forestalled, they would weaken strategic stability, besides opening up a new area of nuclear competition. India's no-first-use pledge would also lose much of its relevance, as a declared second-strike capability could be used for offensive purposes.

\subsection{Conventional Arms Control}

In South Asia's case, the nuclear danger could be reduced significantly if there were a conventional arms control agreement that effectively eliminated the risk of surprise attack and

\footnotetext{
${ }^{69}$ Although speculative, recent estimates indicate that the ratio of weapons-grade material is $3: 1$ or 4:1 in India's favor. According to one estimate, India and Pakistan would have stockpiles for 86 and 36 bombs, respectively, by the year 2000. See "Pakistan's nuclear punch," http://www. abcnews.aol.com/sections/ world/DailyNews/pakistanukes $980513 . \mathrm{html}$. According to Jane's Intelligence Review, if reactor-grade plutonium were included, India could produce 455 bombs while Pakistan could make 83 bombs. See "India, Pakistan can produce more atomic bombs: Report," The Times of India, September 24, 1998.

${ }_{70}$ Refinement of missile systems and development of various atomic devices could raise the possibility of a customized capability for a preemptive strike against a smaller force.

${ }^{71}$ While there is promising support for nondeployment or for "recessed" deterrence in India, provided a sizable arsenal can be operationalized at short notice, there are also influential circles where big-power ambition is more pronounced. See, for example, Brahma Chellany, "India's trial by atom," The Hindustan Times, November 4, 1998. Chellany calls for a "hardy nuclear force, mobile and widely dispersed" and unconstrained by "arms control fetters," based on the maximum number of warheads that can be produced over the next five years, which he conservatively estimates to be under 100 bombs. More disturbing and significant is the study sponsored by the United Services Institute of India, a quasi-military think tank. It has called for over $\$ 15$ billion investment over the next 30 years for a full-fledged land- and sea-based nuclear force consisting of some 350 to 400 nuclear bombs. See Iftikhar Gillani, "India to have nuclear force," The Nation, October 22, 1998. The desire to be treated at par with other nuclear weapon states is also reflected in various statements by Prime Minister Atal Behari Vajyapee. See, for example, "Treat India like other n-states: PM," The Hindu, October 29, 1998. See also Nazir Kamal and Amit Gupta, "Prospects of Conventional Arms Control in South Asia," SANDOC98-0505/5, CMC Occasional Paper 5, November 1998, Sandia National Laboratories, Albuquerque, NM, USA.

${ }^{72}$ See the statement by India's naval chief, Admiral Vishnu Bhagwat, "India Plans a Naval Version of Prithvi Missile," The News, December 1, 1998. The first test of Prithvi-3, a 350-km-range missile, was scheduled for January 26,1999 . India has also reached agreement with Russia for assistance in the manufacture of a nuclearpowered submarine over the next five years.
} 
thereby greatly lowered the danger of conflict. ${ }^{73}$ The complicated and emotive dispute over Kashmir, which encompasses the Siachen battlefield, could again become a source of major conflict. There is also an imbalance of military power between them, which is almost certain to see a further shift in India's favor over the medium term.

As both sides are unlikely to downsize their armed forces unilaterally or even bilaterally, an ambitious arms control approach, such as the Conventional Forces in Europe model, would be considered too drastic as well as too intrusive for verification purposes. An alternative approach could be the creation of force-limitation zones along their border (bolstered by an upgraded UN observer presence along the Line of Control in Kashmir). In this regard, the Sinai-II agreement between Egypt and Israel could serve as a general model.

\subsection{Ban on Large-Scale Military Exercises}

In the post-test period, the avoidance of conflict has become more pressing, both to discourage precipitous moves toward nuclearization and to eliminate the danger of nuclear escalation in a conflict. As such, any military activity that can be perceived as "muscle-flexing" needs to be avoided.

While there is an India-Pakistan agreement for restrictions on certain military exercises, there is no prohibition of large-scale exercises, such as the one conducted by India in November 1998. In keeping with the new situation, the 1991 CBM agreement on military exercises should be updated along with a supplementary ban on integrated (land/air/sea) exercises directed at the other's territory.

\subsection{Prospects of Reducing the Nuclear Danger}

It is encouraging that the nationalistic euphoria, stoked by politicians and some nuclear scientists, died down just as quickly as it arose after the Indian and Pakistani nuclear tests. It soon dawned on many people that the tests had laid open a perilous road ahead.

Some official statements on both sides also showed cognizance of the gravity of the situation confronting these intensely adversarial neighbors. More encouraging have been Pakistani statements advocating restraint and a formal proposal to India in October 1998 for a wide-ranging regime of nuclear, missile, and conventional arms restraint.

While some specific issues such as CTBT and FMCT are being addressed in the extraregional context, ${ }^{74}$ bilateral issues of strategic stability fall under the rubric of "peace and security" in the agenda for India-Pakistan talks agreed to in September 1998. There are, however, some political and conceptual complications.

\footnotetext{
${ }^{73}$ If nuclear weaponization or deployment cannot be effectively forestalled, then some form of conventional arms control would become more urgent. If that happened, Pakistan would only have a nominal interest in maintaining a nuclear capability.

${ }^{74}$ These issues are being discussed bilaterally between the U.S. on the one hand and India and Pakistan on the other. The issue of fissile material control is also being discussed multilaterally at the Conference on Disarmament in Geneva, where negotiations are expected to begin in the near future.
} 
Although India has pledged no first use and said that it is only interested in a "minimum deterrent," it is by no means clear what "minimum" means because it has also said that its deterrent would have to be "credible." India also cited both Pakistan and China as reasons for conducting its nuclear tests. Thus, a "credible" Indian deterrent against China, for example, could mean a highly nuclearized India from the Pakistani perspective, perhaps forcing the latter to make a bigger response than might be the case otherwise.

Nor is it clear to what extent Pakistan will make stabilization measures conditional on progress in resolving the Kashmir dispute. ${ }^{75}$ There appears to be little prospect of a breakthrough on this dispute in the near or even foreseeable future. ${ }^{76}$ In light of the new situation, it is imperative that nuclear stabilization measures should be treated independently.

Given general Pakistani concern about the dangers of nuclear competition, it may be possible to persuade Islamabad to treat stabilization issues as a special case, since a highly dangerous, destabilizing, and expensive process of nuclearization would not be in its interest. ${ }^{77}$ Indeed, given that India seems more interested in nuclearization, Pakistan should take the initiative to stem such a development.

Verification of some proposed measures may also pose problems. Even though Indian and Pakistani NTM are inadequate for unilateral monitoring, these difficulties could be addressed by a third party. For example, the U.S. and Russia could provide supplementary data from their military satellites. An international agency could also be brought into play.

Because of mutual suspicion and national sensitivities, both countries are opposed to bilateral cooperative monitoring or any verification of an intrusive nature. Pakistan seems more amenable to accept a third-party presence in order to obviate an Indian monitoring role in its territory.

Despite public concern about the dangers of nuclearization, there are complicating factors in the nuclear situation in South Asia. The most troubling is the recent hardening of India's position, ${ }^{78}$ while Pakistan has made it clear that it will not accept unilateral restrictions.

Not withstanding these complications, the need for stabilization measures to forestall an unnecessary and expensive nuclear build-up is compelling. Because both sides are still in the process of developing and refining their nuclear capabilities, there is a potential window of

\footnotetext{
${ }^{75}$ Recently, Foreign Minister Sartaj Aziz said: "We have made it clear (to India) that no real progress towards normalisation of relations can be possible so long as the Kashmir dispute remains unresolved." "Pakistan seeks more from India," $B B C$ News, November 4, 1998. This refrain has been a consistent feature of Pakistani policy since the early 1990s. Both sides have also spoken of the "composite" or "comprehensive" nature of their bilateral talks, suggesting linkages, which is also reflected in the pattern of stalemated talks in October and November 1998.

${ }^{76}$ India has shown no sign of flexibility on Kashmir while there are indications that Pakistan would be flexible if India agreed to negotiate a settlement. See, for example, the statement of Prime Minister Nawaz Sharif on August 12, 1998. "Nawaz asks India to make goodwill gesture on Kashmir," The News, August 13, 1998.

${ }^{77}$ There are some signs that Pakistan may treat some peace and security issues on their own merit.

${ }^{78}$ See Kenneth Cooper, "India rejects some arms restraints," The Washington Post, December 16, 1998; and "PM: No cap on production of fissile material," The Times of India, December 16, 1998. Indian Prime Minister Atal Behari Vajpayee said, for example, that "India will define its own requirements, for its nuclear deterrent, on its assessment of the security environment." He also rejected "intrusive or sovereignty violative measures."
} 
opportunity that must not be lost. At the very least, a hair-trigger situation needs to be avoided. Since Pakistan has been relatively more forthcoming, much would therefore depend on India, where the dominant opinion still seems imbued with traditional notions of big-power status.

\section{Conclusions}

India and Pakistan should engage in measures to prevent a buildup of nuclear capabilities and address other aspects of the nuclear danger. A buildup would be difficult to restrict to a bare minimum, and if India chose to develop a deterrent against China, the situation would become more difficult to control and stabilize.

Defense expenditures, too, would increase significantly. Indian and Pakistani defense budgets are already high and under pressure for more allocation for conventional force modernization and improving the conditions of military service.

More important, a buildup of capabilities would create a hair-trigger situation that would be exacting to manage in peace time if tensions rose sharply, as has been the pattern of IndiaPakistan relations. The situation would become more precarious if a conflict started. There are numerous potential targets on both sides of the border, especially on the Pakistani side, that are well within ten minutes of missile launch.

Other concerns would be the safety and security of warheads and weaponized delivery systems, especially the risk of unauthorized launch and accidents. Another problem would be distinguishing nuclear-armed from conventionally armed missiles.

Pakistan has proposed strategic stabilization measures, including nondeployment, while India has proposed more modest confidence-building measures. It is to be hoped that by the next round of bilateral talks in February 1999, they would have found some common ground.

As a first step, India and Pakistan should refine their nuclear doctrines. India's no-firstuse pledge would lose its value if it developed a deterrent, especially on the scale being advocated by some Indian quarters. There is no compelling security need to move in that fateful direction. India should therefore reinforce its no-first-use pledge with nonweaponization or nondeployment, preferably both.

Pakistan's declared nuclear doctrine also needs fine-tuning so that it is linked to rational and realistic strategic objectives. Over-reliance on nuclear deterrence would be financially exorbitant and a dangerous way of strengthening its security.

Mutual suspicion and national sensitivities may, however, restrict the scope of measures to achieve strategic stabilization, as agreements for nonweaponization or nondeployment would require means of monitoring compliance that may be deemed too intrusive.

A modest approach could consist of a tacit understanding for nonweaponization and nondeployment of delivery systems and for a discreet mechanism for clarifying or correcting controversial situations. As a first step, they could announce a moratorium. 
For nondeployment, they could also consider storing Transporter/Erector/Launchers (TELs) of missiles in designated sites, thereby leaving out the sensitive issue of monitoring missiles. Again, regional NTM may need supplementation by third-party satellite reconnaissance and periodic on-site monitoring of TELs.

Nondeployment could also cover specific categories of nuclear-capable aircraft in all forward air bases. Another measure could be an appropriate extension of the no-fly zones agreed to in the 1991 accord on preventing air-space violation. The extended zone could cover only specified categories of aircraft.

While unmitigated adversaries may balk at intrusive verification measures, some form of monitoring would be necessary to ensure strategic stability and build mutual confidence. It could be designed to minimize intrusiveness.

The nuclear danger could also be reduced through conventional stability, as a nuclear exchange could arise from an escalation of conventional conflict. A force-limitation zone along the border would lower armament levels in forward positions and eliminate the threat of surprise attack, thereby greatly reducing the risk of conflict.

Finally, India and Pakistan should treat the issues of strategic stabilization and restraint as a special case, so that progress in this area does not depend on the overall progress of their bilateral talks, as that could mean a dangerously indefinite wait. 


\section{About the Author}

Nazir Kamal is a freelance security analyst who previously worked as a Senior Fellow at the Institute of Strategic Studies in Islamabad. His other positions include Director in the Office of the Advisor to the Prime Minister on Foreign Affairs, and Consultant to the United Nations Department for Disarmament Affairs. He obtained his Ph.D. degree from the Australian National University in Canberra and his Master's degree from the University of Sussex in England, both in the field of International Relations. 


\section{Distribution}

300 MS 1373 CMC Library, 5341

1 MS 9018 Central Tech Files, 8940-2

2 MS 0899 Technical Library, 4916

1 MS 0619 Review \& Approval Desk, 15102 for DOE/OSTI 